\title{
REMOTE SENSING OF VEGETATION RECOVERY IN GRASSLANDS AFTER THE 1988 FIRES
}

\author{
EVELYN MERRILL $\bullet$ DEPARTMENT OF ZOOLOGY AND PHYSIOLOGY \\ RON MARRS $\bullet$ DEPARTMENT OF GEOLOGY \\ UNIVERSITY OF WYOMING $\bullet$ LARAMIE
}

\section{- INTRODUCTION}

Traditional methods for measurement of vegetative biomass can be time-consuming and laborintensive, especially across large areas. Yet such estimates are necessary to investigate the effects of large scale disturbances on ecosystem components and processes. One alternative to traditional methods for monitoring rangeland vegetation is to use satellite imagery. Because foliage of plants differentially absorbs and reflects energy within the electromagnetic spectrum, remote sensing of spectral data can be used to quantify the amount of vegetative biomass present in an area (Tucker and Sellers 1986).

In 1987 we found that Landsat Multispectral Scanner (MSS) imagery could be used to quantify green herbaceous phytomass (GHP) on ungulate summer range in the northeastern portion of Yellowstone National Park. Estimates of GHP in the study area were well within values reported for the habitat types sampled (Mueggler and Steward 1980). Annual variation in GHP was related to winter snow accumulation probably due to the timing of snow melt (Merrill et al. 1988). Additionally, we found that GHP explained a significant amount of the variation in the per capita growth rate of elk population from 1972 to 1987 (Merrill and Boyce 1991).
The extensive fires that occurred in the Park in the summer of 1988 provided an opportunity to determine whether remote sensing could be used to monitor grassland vegetation recovery in the Park and to explore the effects of the 1988 fires on ungulate populations using models we developed in 1987. Previous studies have used Landsat imagery to monitor succession of seral stages after fire in pine (Jakubauskas et al. 1990), but no studies to our knowledge have used this approach to quantify herbaceous recovery in grasslands.

The objectives during this study period were:

(1) to develop and validate a model for predicting GHP in sagebrush-grassland communities using 1989-91 Landsat TM spectral information and field data on GHP; and

(2) to describe broad-scale vegetation recovery in burned areas and physiographic and soil features which influence the recovery.

\section{- STUdY AREA}

The study was conducted in the northeast portion of Yellowstone National Park with major focus on the upper Lamar, Cache and Calfee River drainages and the Mirror Plateau. Elevations range from 1,500 to 
$3,300 \mathrm{~m}$. Descriptions of vegetation communities in the park are given by Despain (1990). Our work focused on the non-forested plant communities within the study area. These included sagebrush (Artemisia tridentata) communities which have an understory of bluebunch wheatgrass (Agropyron spicatum) in dry areas and Idaho fescue (Festuca idahoensis) on the more mesic sites. Silver sagebrush (Artemisia cana) with an Idaho fescue co-dominant is found on areas associated with high water table such as streambanks and seeps. High elevation grasslands are dominated by Idaho fescue/tufted hairgrass (Deschampsia cespitosa) and tufted hairgrass/sedge (Carex spp.). At intermediate elevations, Idaho fescue/wheatgrass (Agropyron spicatum and A. caninum) communities are encountered with the latter dominating in the more mesic sites.

\section{- METHODS AND RESUlTS}

\section{VEGETATION DATA COLLECTION AND ANALYSIS}

Vegetation data were collected at 50 groundtruth sites from 25 July-10 August, 1989, 30 July-11 August, 1990, and 30 July-13 August, 1991 across two elk summer ranges (Norris/Cache/Calfee Ridge complex and Mirror Plateau). Twenty-two sites have been resampled each year. Each site encompassed at least 0.81 hectares ( 2 acres or approximately 9 landsat pixels) of homogeneous vegetation. At each site physiographic characteristics were recorded using topographic 1:24,000 maps. Grassland habitat types followed Yellowstone National Park habitat mapping (Despain 1990).

Vegetation was sampled and analyzed using a double sampling approach (Merrill et al. 1988). At each site, percent cover of graminoids, forbs, bare ground, rock, moss, lichens and wood were estimated. Average heights of plants within forage classes were also measured and an index to plant volume was calculated as canopy cover $\mathrm{x}$ average plant height. Shrub cover was measured using line intercept method.

Ten of the 30 microplots at each site were clipped to ground level. Vegetation was separated into green graminoids, green forbs and standing dead. A criterion of $>25 \%$ "green" was used to differentiate green from standing dead plants. Biomass samples were dried at $70^{\circ}$ for 48 hours and weighed to the nearest $0.1 \mathrm{gm}$. All weights are reported as oven-dry weights. The relationship between plant volume and biomass was determined using a least squares multiple regression analysis.

\section{LANDSAT DATA ACQUISITION AND ANALYSIS}

Landsat Thematic Mapper (TM) imagery of the study area was acquired for 2 August 1989, 13 August 1990, 6 August from EOSAT by the National Park Service. Digital Landsat data were transferred from 9-track computer tapes to the Micro-computer Image Processing System (MIPS) for data processing. At each of the 50 sites the spectral values of 9 contiguous pixels were averaged for each of the 6 TM bands. Linear combinations of TM spectral values as well as published vegetation indices are being developed. The perpendicular vegetation index (PVI), and the green vegetation index (GVI) will be derived using the Graham-Schmidt Orthogonalization process (Frieberger 1960 in Jackson 1983). Jackson (1983) showed that these indices minimize soil background variations while improving green vegetation signals. Relationships between the averaged TM band spectral values and their various vegetation indices and phytomass estimates are being determined using liner and nonlinear least squares multiple regression analysis. However, to conduct these analyses, Landsat data from the different years must first be calibrated for differences related to changes in instrument sensitivity, electronic gain and bias (Markham and Barker 1986).

Currently, we are evaluating several spectral relationships built from a subset of the field data and the 1989-91 Landsat spectral data. Models which meet established criteria (relationships which have significant $F$ values $(\mathrm{P}<0.05)$; account for $>50 \%$ of the variance in the field data collected; highest precision) will be further evaluated by comparing their predictions using field data not used in the model building process. Topographic, soils, aspect, slope and elevational data have been put into our GIS and will be used to explore patterns of vegetation recovery.

\section{- Literature Cited}

Despain, D. G. 1990. Yellowstone vegetation: consequences of environment and history in a natural setting. Roberts Rinehart Publishers. Boulder, CO. 239 pp. 
Jackson, R. D. 1983. Spectral indices in n-Space. Remote Sens. Environ. 13: 409-421.

Jakubauskas, M. K. P. Lulla and P. W. Mausel. 1990. Assessment of vegetation change in a firealtered forest landscape. Photogr. Eng. Remote Sens. 56:371-377.

Markham, B. L. and J. L. Baker. 1986. Landsat MSS and TM post calibration dynamic ranges, exoatmospheric reflectances and at-satellite temperatures. EOSA Landsat Tech. Rep. Note 1:3-8.

Merrill, E. H., M. S. Boyce, R. W. Marrs, and M. Bramble-Brodahl. 1988. Relationships among climatic variation, grassland phytomass and ungulate population characteristics on the Northern Range of Yellowstone National Park. Final Rep. Univ. Wyoming Research Center-National Park Service.
Merrill, E. H. and M. S. Boyce. 1991. Summer range and elk population dynamics in Yellowstone National Park. Pages 263-272 In The Greater Yellowstone Ecosystem: Redefining America's wilderness heritage. R.B. Keiter and M.S. Boyce (eds). Yale Univ. Press.

Mueggler, W. R. and W. L. Stewart. 1980. Grassland and shrubland habitat types of western Montana. USDA For. Serv., Gen Tech. Rep. Int66. $154 \mathrm{pp}$.

Tucker, C. J., and P. J. Sellers. 1986. Satellite remote sensing of primary production. Int. J. Remote Sensing 7:1395-1414. 